\title{
O TRUDNEJ SZTUCE OBYWANIA SIĘ BEZ GRANIC
}

\begin{abstract}
Lisiecki Stanisław, O trudnej sztuce obywania się bez granic [On the difficult art of dispensing with boundaries] edited by J. Kubera, Ł. Skoczylas - "Człowiek i Społeczeństwo", vol. XXXVII, Poznań 2014, pp. 13-25, Adam Mickiewicz University Press. ISBN 978-83-232-2764-9. ISSN 0239-3271.

The author focuses on demonstrating that, contrary to the currently popular thesis of the disappearance of the "old" borders, in many cases we can talk about the emergence of "new" borders and the renaissance of ethnic boundaries (Scotland, Catalonia, Silesia). The text discusses the phenomenon of ethnic segmentation in multi-ethnic and multicultural cities. It gives an example of German cities (Berlin, Frankfurt am Main and cities in North Rhine-Westphalia). The author shows that talking about the end of the borders appears to be too early and that it is still worth dealing scientifically with the socially constructed borders.
\end{abstract}

Stanisław Lisiecki, Uniwersytet im. Adama Mickiewicza w Poznaniu, Instytut Socjologii, ul. Szamarzewskiego 89c, 60-568 Poznań, Poland.

\section{WSTĘP}

Truizmem wydaje się dzisiaj stwierdzenie, że granice współczesnych państw stają się bardziej przenikliwe; w Europie spowszedniało hasło o "kontynencie bez granic". W Polsce, która po 1989 roku otwarła większość swoich granic, zdążyliśmy się już przyzwyczaić do sytuacji „po Schengen” i możliwości swobodnego przemieszczania się pomiędzy krajami Unii Europejskiej. Z tego względu nie dziwi fakt, że w wielu publikacjach podkreśla się, iż nie ma już granic w znaczeniu fizycznym, wszyscy jesteśmy w ruchu. Jak pisze Michael Benedikt, „zaczyna się kwestionować w ogóle znaczenie położenia geograficznego, niezależnie od skali. Stajemy się nomadami, którzy stale są w kontakcie" (za: Bauman 2000: 93).

Przekonany o końcu granic fizycznych jest także francuski architekt i filozof Paul Virilio, który krytykując Francisa Fukuyamę za jego koncepcję końca historii, stawia tezę o końcu geografii. We współczesnym świecie, jego 
zdaniem, odległości i granice, podobnie jak wszelkie opozycje w rodzaju "tutaj” i "tam” czy "blisko" i "daleko”, tracą na znaczeniu. Tym samym mniej ważne stają się również podziały w obrębie globu i poszczególnych kontynentów, ponieważ wynikały z odległości, która dzisiaj traci na znaczeniu (Virilio 2008: 171). Wcześniej tezę o „śmierci geografii” formułowali także futurolodzy, np. Alvin Toffler (1974). Współcześnie o zmieniających się funkcjach granic pisała między innymi Patricia Zander (2010) w ukazującym się w Poznaniu czasopiśmie geograficznym "Quaestiones Geographicae”.

\section{1. ŚLĄZACY I KASZUBI. ODRADZANIE SIĘ TOŻSAMOŚCI REGIONALNYCH}

Sytuacji, w której granice państw tracą na znaczeniu, towarzyszy wzrost zainteresowania granicami etnicznymi, czego przykładem może być Wielka Brytania, gdzie trwają procedury "odgradzania się" Szkocji od Anglii (ostatecznie o przyszłości Szkotów ma zadecydować referendum, które odbędzie się pod koniec 2014 r.). Z podobnym procesem mamy do czynienia na pograniczach innych państw narodowych, np. w Hiszpanii, gdzie analogiczne zabiegi wszczęła Katalonia, czy w Polsce, czego przykładem może być wzrost zainteresowania tożsamością regionalną, połączony z próbą legalizacji narodowości śląskiej.

Ślązacy od pokoleń podkreślali swoją odrębną identyfikację, a spis powszechny z 2002 roku ujawnił, że stanowią oni największą, bo liczącą 173 tys. osób, mniejszość narodową (chociaż oficjalnie taki naród nie istnieje). Ostatni spis narodowy z 2011 roku, w którym w odróżnieniu od spisu z 2002 roku można już było podać przynależność do dwóch narodowości, wykazał, że 809 tys. osób zadeklarowało narodowość śląską. Jako jedyną swoją narodowość wskazały ją 362 tys. osób, zaś 415 tys. połączyło ją z polską („Gazeta Wyborcza” 23.03.2012). Aby odpowiedzieć na pytanie, skąd taki wzrost liczby osób deklarujących narodowość śląską, trzeba cofnąć się o wiele lat i przypomnieć badania Józefa Chałasińskiego (1935) oraz Stanisława Ossowskiego (1970 [1947]), do których nawiązała w latach dziewięćdziesiątych XX wieku Antonina Kłoskowska (1996).

$\mathrm{W}$ badaniach przeprowadzonych na pograniczach polsko-białoruskim i polsko-ukraińskim oraz na Opolszczyźnie A. Kłoskowska wykorzystała, podobnie jak kiedyś J. Chałasiński i S. Ossowski, materiał autobiograficzny, umożliwiający poznanie rozmaitych aspektów zróżnicowania regionalnego i różnych odmian pogranicznych sytuacji narodowych. Nawiązała w ten sposób do bogatej tradycji badań autobiograficznych na Ziemiach Zachod- 
nich i Północnych, określanej w literaturze przedmiotu mianem fenomenu. Tylko w latach 1945-1970 odbyło się ponad 400 konkursów autobiograficznych, w tym 27 ogłoszonych przez instytucje naukowe. A. Kłoskowska zebrała materiał badawczy, rejestrując na taśmie magnetofonowej wywiady przeprowadzone $\mathrm{z}$ siedemdziesięcioma osobami. Swoimi badaniami objęła dwie kategorie: starszych (powyżej 60. roku życia) i młodszych (urodzonych pomiędzy 1961 a 1970 rokiem). Starsi pochodzili głównie z okolic Raciborza, młodsi to studenci pochodzacy ze wsi opolskich. W badaniach nie znalazła się grupa wielkich Poloków, o których pisał S. Ossowski. Zgodnie bowiem $\mathrm{z}$ założeniami chodziło o mniejszości narodowe, dlatego $\mathrm{w}$ badaniach nie uwzględniono autochtonów. Natomiast zostały też wykorzystane materiały zastane o charakterze autobiografii: dzienniki i wspomnienia.

W badaniach nad tożsamością ludności Śląska Opolskiego A. Kłoskowska (1996: 162) uwzględniła dwa aspekty tego zjawiska: identyfikację narodową i walencję kulturową, oznaczającą poczucie związku z kulturą etniczną lub narodową uważaną za własną. Wykorzystując zebrane materiały i przeprowadzając analizę, autorka wyróżniła cztery typy identyfikacji narodowej tej grupy: 1) jednolitą (integralną), 2) podwójną, 3) niepewną, 4) kosmopolityczną. Biorąc pod uwagę poczucie związku z kulturą, wyróżniła cztery typy jej przyswojenia: 1) uniwalencję, 2) biwalencję, 3) ambiwalencję, 4) poliwalencję. Zakładała przy tym, że każda jednostka ze względu na identyfikację narodową może $\mathrm{w}$ danym momencie swojego życia i w danej sytuacji reprezentować więcej niż jedną identyfikację. Natomiast różne typy walencji mogą trwale występować w świadomości tej samej jednostki.

Jako wzorcowy przykład autobiografii starszego pokolenia A. Kłoskowska potraktowała życiorys 62-letniej kobiety. Pochodziła ona z wielodzietnej rodziny tkaczy. Ojciec, członek SS podejrzany o komunizm, został zesłany do Groß-Rosen. Ją wraz z resztą rodziny wywieziono w okolice Berlina, gdzie $z$ racji słowiańskiego nazwiska zaczynającego się na $M$, nazywano ją Molotow. Po powrocie - jak mówi - było jeszcze gorzej: „Tam byliśmy Molotow, tutaj, no to - Szwaby" (Kłoskowska 1996: 245).

Wydarzenia wojenne i ewakuacja to główne motywy autobiografii Ślązaków starszego pokolenia. Opis tych wydarzeń zajmuje dużo miejsca, szczególnie $\mathrm{w}$ relacjach kobiet, zawierając wiele faktów drastycznych (rabunki, gwałty). Wobec tamtych przeżyć A. Kłoskowska stawia dość względnie pytanie o identyfikację narodową: „Ludzie różnie sądzą na ten temat. A za członka jakiego narodu Pan(i) się uważa?" (Kłoskowska 1996: 248). Odpowiedzi układają się tutaj, tworząc pewną skalę: „Niemka, Niemiec; bardziej jestem Niemcem; byłam Niemką, a teraz jestem Niemką i Polką; Niemka i Polka [...] jeszcze trochę Ślązaczka; chyba Polka; no Polka, ale 
Ślązaczka”, a ponadto choćby spontanicznie sformułowane zdanie: „my, biedni ludzie".

Badania w grupie starszej obejmowały ludzi mniej niż średnio wykształconych, wśród których kontakt z nauką języka niemieckiego został przerwany w wieku kilkunastu lat. Może dlatego ich walencje kulturowe są przepełnione związkami z obyczajowością i obrzędami religijnymi, a tylko częściowo z elementami wiedzy historycznej. Dominowała biwalencja, co stwierdził sam autor niniejszego artykułu w czasie pobytów stypendialnych w Niemczech, np. w czasie obchodzenia Wigilii czy podczas innych spotkań przesiedleńców w Niemczech, gdzie chętnie śpiewa się polskie kolędy i piosenki. Generalnie przedstawiciele starszego pokolenia wykazują chwiejność w rozumieniu i odczuwaniu rozróżnienia „niemieckości” i „polskości”. Może dlatego szczególnie podkreślają wartość ojczyzny - mowy, której się nie zapomina. Świadczy o tym, cytowany przez jedną z rozmówczyń badaczki (nazwanej przez A. Kłoskowską „Pośredniczką") i tłumaczony przez nią na język polski, wiersz (Kłoskowska 1996: 250): „To jest moje Heimat. Tu jest mój dom. To jest takie miejsce malutkie [...]. Ale to jest moje. Tu żyję, tu kocham, tu ja odpoczywam. A to jest moje Heimat [...]. To jest nauka kobiety, która ma sześćdziesiąt lat, a miała trzynaście lat, jak skończyła niemiecką mowę. Tylko, że ta niemiecka mowa pozostała".

W autobiografiach młodych Ślązaków problem identyfikacji narodowej zajmuje wiele miejsca. Najczęściej używanym określeniem identyfikacji narodowej jest tu "Ślązak-Polak”. Pełna skala tych identyfikacji wyraża się w następujących określeniach: „osoba o orientacji niemieckiej; Ślązak-Niemiec; nie Polak; bardziej Niemiec niż Polak (lub Niemiec-Ślązak-Polak); Ślązak; Ślązak-Polak; Polak-Ślązak; Kosmopolita" (Kłoskowska 1996: 254).

Tożsamość młodych Ślązaków, która - jak widać z powyższego wyliczenia - nie ogranicza się do polskich lub niemieckich identyfikacji narodowych, ale obejmuje także poczucie regionalnej etnicznej swojskości, wpływa na walencje kulturowe młodzieży na tym terenie. Charakterystycznym wskaźnikiem narodowej walencji kulturowej są dla A. Kłoskowskiej wartości uznawane za charakterystyczne dla "swoich" i "obcych" oraz różne dziedziny kultury symbolicznej. Tego pierwszego zagadnienia dotyczyło pytanie o takie wartości, jak pracowitość czy porządek, natomiast tego drugiego - pytanie o zainteresowania kulturalne i kanon kultury.

Przytoczone przez badaczkę przykłady świadczą o sporej rozbieżności pomiędzy deklarowaną identyfikacją narodową a elementami walencji kulturowej. Przykładem mogą być wypowiedzi, których autorzy nie deklarują niemieckiej identyfikacji narodowej, ale wzmiankują o śpiewaniu Heimatmelodien czy piszą o kultywowaniu w swoich domach przekazów o związ- 
kach rodzinnych z rodami pruskimi (Kłoskowska 1996: 264). Jest też wiele wypowiedzi, które utrudniają jednoznaczne rozróżnienie pomiędzy bi- lub poliwalencją. Jak wynika z analizy A. Kłoskowskiej, autorzy cytowanych wypowiedzi starają się ten problem rozwiązać, odwołując się do związków z "małą" i "wielką" ojczyzną (Heimat i Vaterland). Dominują deklaracje przynależności do małych ojczyzn: Heimat jest określany jako miejsce „najbliższe, cząstka siebie", miejsce, w którym ,jestem zakorzeniony" (Kłoskowska 1996: 266). Silniejszy związek Ślązaków z Heimatem niż z Vaterlandem widoczny jest też w obserwowanych w Niemczech sytuacjach (o czym przekonał się również autor w trakcie pobytów w Niemczech), gdy Ślązacy, którzy wyemigrowali do Niemiec z danej miejscowości lub okolicy, tworzą lokalne getta, w których mówi się po Śląsku (Kłoskowska 1996: 266).

"Odgradzanie się" Ślązaków jest, jak się zdaje, skutkiem elementarnego dla wszystkich grup społecznych dzielenia na "swoich" i „obcych”, ale i wyrazem lęku przed narzucaniem obcych wartości. Ten lęk widoczny jest także w stereotypie Ślązaka (Kłoskowska 1996: 272): „...Ślązak był zawsze taki wystraszony. I on w tej skorupie strachu po prostu siedział [...] tak jak żółw, aż musiał wyjrzeć i naprawdę już nie widzieć nic, co by mu mogło zagrozić". Odgradzanie się od obcych może być też wyrazem lęku przed byciem odrzuconym; mówią o tym osoby zintegrowane z polską kulturą, wspominające o tym, że "język ich zdradzał" lub że w pewnych sytuacjach „nie przyznawali się otwarcie do swojej śląskości” (Kłoskowska 1996: 272).

W większości życiorysów młodych Ślązaków widoczne jest poszukiwanie odpowiedzi na pytanie: „kim jestem?”. Dylemat ten można dostrzec we wspomnieniach dotyczących tzw. narodowościowej weryfikacji ludności rodzimej, przeprowadzanej na przełomie lat czterdziestych i pięćdziesiątych ubiegłego wieku w Polsce. Zbigniew Kurcz w swojej relacji z badań nad mniejszością niemiecką w naszym kraju cytuje następującą wypowiedź jednej z osób podlegających takiej właśnie weryfikacji (Kurcz 1995: 167):

Jedną z bardziej bolesnych spraw była przymusowa zmiana niemieckich nazwisk i imion. W zależności od gorliwości urzędników przebiegało to bardziej lub mniej konsekwentnie. Dotknęło to oczywiście i członków mojej rodziny (z wyjątkiem mojego i siostry imienia). W dokumencie z 1948 roku, o ironio, jest zaznaczone, że wszyscy poddali się tym zmianom dobrowolnie. Zagrożono odebraniem kartek żywnościowych tym, którzy mieliby odwagę się sprzeciwić. Faktem jest, że Niemcy w czasach hitlerowskich dokonali podobnego zamachu na polskie nazwy miejscowości, nazwiska i imiona, ale przecież Polacy zawsze tę germanizację potępiali - polonizację zaś uważali za słuszną i uzasadnioną (bo to Kali ukradł krowę). Większość naszych obywateli nigdy nie zaakceptowała swych nowych personaliów. Figurowały tylko w aktach urzędowych, a wśród bliskich używane były te dawne, co nieraz 
doprowadzało do pomyłek i nieporozumień. To zrozumiałe, że ludzie nie byli w stanie tego przyjąć, bo zmienić dorosłemu człowiekowi imię czy nazwisko, to tak jakby odebrać mu jego tożsamość, kazać mu nagle być kimś innym.

Pozwólmy sobie w tym miejscu na pewną dygresję. W spisie powszechnym z 2011 roku na drugim miejscu wśród mniejszości znalazła się mniejszość kaszubska (228 tys., przy czym dla 17 tys. był to pierwszy wybór). Biorąc pod uwagę spis z 2002 r., jest to istotna zmiana, bo w spisie tym na drugim miejscu była mniejszość ukraińska, a przynależność do mniejszości kaszubskiej deklarowało nieco ponad 5 tys. osób (Chałupczak, Michalik 2006: 268). Obecnie, jak wykazuje Marek Latoszek, liczbę ludności kaszubskiej szacuje się na około 300 tys., chociaż liczba ludności z tzw. syndromem kaszubskości wynosi ponad pół miliona (Latoszek 1990). Może dlatego głośno było o akcji stowarzyszenia Kaszëbskô Jednota i Stowarzyszenia Osób Narodowości Śląskiej, które złożyły wniosek do rządu i marszałka Sejmu o uznanie tych mniejszości za mniejszości narodowe.

Z drugiej strony - jak podkreśla wielu badaczy - na Kaszubach tożsamość regionalna istnieje jednocześnie z tożsamością narodową: „Na Kaszubach występuje podwójna świadomość - narodowa polska i regionalna kaszubska. Każda z nich jest odrębna, chociaż za nadrzędną uważa się świadomość narodową. W życiu codziennym Kaszuba bywa Kaszuba, w życiu uroczystym i oficjalnym Kaszuba i Polakiem" (Synak 2000: 513). Badania socjologiczne wykazują też, że w przypadku Kaszubów mamy do czynienia z grupą o wyraźnie ukształtowanej tożsamości jednostkowej (autoidentyfikacji) i grupowej. Jak pisze Brunon Synak: „Gdy na badanym terenie pytano mieszkańców, czy czują się Kaszubami, to przytłaczająca większość osób o rodowodzie w pełni lub częściowo «kaszubskim» (90-95\%) odpowiadała twierdząco (podobny poziom autoidentyfikacji występuje również u dzieci szkolnych)" (Synak 2000: 513).

W literaturze przedmiotu wielu autorów podkreśla, że zarówno Śląsk, jak i Kaszuby należy postrzegać w perspektywie regionów długiego trwania. Pisze o tym Marek Szczepański w kontekście Śląska, dodając, że jest to przykład regionu pogranicza poddawanego przez setki lat wpływom politycznym i ekonomicznym Czech, Moraw, Prus i Austrii (Szczepański 1999: 14):

Górny Śląsk zatem, region pogranicza kulturowego, postrzegany być winien w perspektywie długiego trwania. Termin ten (la longue durée) wprowadził do nauk społecznych znakomity uczony francuski Fernand Paul Braudel, współtwórca historycznej szkoły Annales [...]. Sądził on, że głównym zadaniem historyka, socjologa czy ekonomisty nie może być najbardziej nawet skrupulatna, rzetelna i wyczerpująca 
rejestracja faktów. Uczony reprezentujący nauki społeczne winien raczej opisywać struktury i instytucje opierające się w znacznym stopniu fluktuacjom politycznym i rzutujące na współczesne przeobrażenia.

W podobnym kontekście o Kaszubach mówi B. Synak, według którego wykorzystują oni własną przeszłość (polską, krzyżacką, pomorską), konstruując obraz swojej kulturowo-etnicznej tożsamości (Synak 2000: 329). Dlatego też, moim zdaniem, debata nad nowymi mniejszościami przebiegać winna w szczególnym kontekście, który wyznacza dyskusja nad "starymi” $\mathrm{i}$,"nowymi” granicami etnicznymi.

\section{SEGMENTACJA ETNICZNA W MIASTACH. CASUS MIAST NADRENII PÓŁNOCNEJ-WESTFALII W NIEMCZECH}

Zanikowi "starych" granic towarzyszy powstawanie "nowych" o charakterze symboliczno-tożsamościowym (Babiński 2001: 27). Terenem powstawania tych drugich stają się współcześnie wielkie miasta, z jednej strony miejsce koncentracji migrantów zarobkowych, z drugiej - teren segregacji etnicznej, czego przykładów dostarczają miasta niemieckie. Miasta te, zwłaszcza w drugiej połowie XX wieku, odnotowały znaczny napływ cudzoziemców. Szczególny wzrost liczby robotników cudzoziemskich (tzw. Gastarbeiterów) odnotowano w połowie lat sześćdziesiątych, kiedy to - wskutek zamknięcia granicy z NRD - nastąpił wzrost popytu na zagraniczną siłę roboczą. Podpisano wówczas układy o zatrudnieniu obcej siły roboczej: z Włochami (1955), Hiszpanią (1964), Grecją (1960), Turcją (1961), Tunezją (1964) oraz Jugosławią (1968) (szerzej: Lisiecki 1991). W 1973 roku robotnicy cudzoziemscy stanowili 11,9\% ogółu zatrudnionych w RFN (dla porównania, w 1960 roku - 1,3\%). Gwałtowne załamanie się koniunktury w latach 1973-1975 zapoczątkowało spadek ich liczby. W listopadzie 1973 roku wprowadzono zakaz zatrudniania nowych robotników cudzoziemskich (Anwerbestopp). Od tego czasu teoretycznie żaden obcokrajowiec pochodzący z krajów nieprzynależnych do Europejskiej Wspólnoty Gospodarczej (EWG) nie może podać jako celu przyjazdu chęci podjęcia pracy.

Kryzys i decyzja o zastopowaniu zatrudniania nowych robotników cudzoziemskich w różny sposób wpłynęły na poszczególne grupy narodowościowe. I tak, RFN opuściła prawie 1/3 robotników włoskich i hiszpańskich, natomiast liczba Turków prawie się nie zmieniła. Liczba Jugosłowian, Portugalczyków i Greków zmniejszyła się o około 15-20\% (Lisiecki 1991: 17). 
W następującym po zakazie zatrudniania cudzoziemców pięcioleciu (1973-1978) liczba robotników cudzoziemskich zmalała do 1,9 mln osób. Odsetek robotników cudzoziemskich wśród ogółu zatrudnionych spadł do 9,1\%. W tym samym jednak czasie liczba cudzoziemców przebywających w RFN wzrosła, przede wszystkim na skutek akcji łączenia rodzin, do $4 \mathrm{mln}$. Wbrew posunięciom administracyjnym ustabilizowała się też liczba bezrobotnych robotników cudzoziemskich. W okresie kryzysu 1967/1968 bezrobocie w tej grupie było dwukrotnie większe niż wśród robotników zachodnioniemieckich $(11,6 \%$ wobec $5,2 \%)$. Sytuacja ta nie powtórzyła się już w 1973 roku. Tylko na początku recesji procent bezrobotnych wśród robotników cudzoziemskich był nieco większy od przeciętnej. Potem, gdy część $\mathrm{z}$ nich wyjechała, okazało się, że stopa bezrobocia $\mathrm{w}$ tej grupie jest podobna do stopy ogólnej - dotyczącej całego społeczeństwa zachodnioniemieckiego (Lisiecki 1991: 18).

Bez wątpienia 1973 rok stanowił pewną cezurę. Oddzielała ona okres dynamicznego wzrostu liczby robotników cudzoziemskich od okresu, w którym poważnie spadła ich liczba. Była to również cezura w polityce dotyczącej tej grupy. W 1985 roku liczba robotników cudzoziemskich przekroczyła 1,6 mln, a liczba wszystkich cudzoziemców ustabilizowała się na poziomie $4,3 \mathrm{mln}$. Nadal jednak RFN stała na stanowisku, że nie jest krajem migracji, ponieważ, jak podkreślano, kraj ten nie miał wolnej przestrzeni do zagospodarowania. Nie była krajem migracji, bo w tym samym czasie miała 2,5 mln bezrobotnych. $Z$ drugiej strony, jeśli nawet RFN nie można było wówczas nazwać de iure krajem migracji (tj. z wolną przestrzenią i miejscami pracy), to był to już wówczas z pewnością kraj wieloetniczny. Migrujący robotnicy cudzoziemscy wprowadzili w ruch te same procesy, których terenem były kiedyś Stany Zjednoczone.

Rychło też, tak jak kiedyś w społeczeństwie amerykańskim - chociaż w znacznie mniejszej skali - pojawił się problem przestrzennego rozmieszczenia cudzoziemców w miastach zachodnioniemieckich. Przykładem może być Frankfurt nad Menem, swego czasu miasto o największej w RFN koncentracji robotników cudzoziemskich. Stanowili oni pod koniec lat osiemdziesiątych 25\% ogółu mieszkańców, a odsetek ich dzieci do lat sześciu przekraczał nawet 30\% (Lisiecki 1991: 147). Po zjednoczeniu Niemiec liczba cudzoziemców nie uległa zasadniczo zmianie i w 2009 roku wynosiła 6674 tys., w tym 2367 tys. obywateli Unii Europejskiej, 1658 tys. Turków, 268 tys. Afrykanów, 815 tys. obywateli państw azjatyckich (zob. Statistisches... 2010: 48-54).

Przykładem miasta z dużym odsetkiem obcokrajowców jest obecnie Berlin, największe skupisko diaspory tureckiej w Europie. Szczególnym przy- 
padkiem dzielnicy, gdzie liczba obcokrajowców przekracza 1/3 (w niektórych częściach prawie 60\%) jest Kreuzberg, z którego po wybudowaniu muru berlińskiego wyemigrowało prawie 150 tys. Niemców. W 1996 roku ludność pochodzenia tureckiego stanowiła 31\%, a skupiona była w większości wokół dzielnicy Marienplatz, zwłaszcza Wiener Straße (Kleff 1999: 83-88). Podobnie jak w przypadku miast amerykańskich, widoczna staje się zależność segregacji etnicznej i społecznej. Widać to na przykładzie stopy bezrobocia wśród obcokrajowców, która w Berlinie kształtuje się na poziomie 34\% (Ghettos oder... 1999: 9-10).

Miastem z największym odsetkiem mieszkańców wywodzących się spoza Niemiec (w 1996 roku - 28,6\%) pozostaje liczący ponad 700 tys. osób Frankfurt nad Menem. Już wcześniej (w latach siedemdziesiątych) przeprowadzone badania, wykorzystujące indeks dysymilacyjny i indeks koncentracji, wykazywały, że powstają tam dzielnice o dużej koncentracji robotników cudzoziemskich (Lisiecki 1991: 177-178). Tym, co różni Berlin i Frankfurt, jest fakt, iż segregacja wynikająca z różnic socjalnych jest we Frankfurcie większa niż ta wynikająca z różnic etnicznych. Szacuje się, że tylko 5-10\% obcokrajowców mieszka tam w odrębnych (segregierten) dzielnicach miasta. Tam też liczba osób korzystających z pomocy społecznej jest wyższa niż wśród rdzennych Niemców (Wolf-Almanasreh 1999: 103-104).

Bardziej wnikliwa analiza nierówności społecznych wykazuje jednak, że wiele takich obszarów miasta nazwać można „obszarami nawarstwiających się problemów" (Multiproblemzonen), tak jak w śródmieściu Frankfurtu, gdzie segregacja etniczna i społeczna nakładają się. Są też dzielnice, np. okolice dworca kolejowego, gdzie wysoki odsetek obcokrajowców koreluje $\mathrm{z}$ wysoką przestępczością. Potencjalnym polem kontrowersji staje się też różnorodność religijna (we Frankfurcie istnieje około 110 różnych wspólnot religijnych). Wskazują na to konflikty społeczne ujawniające się w czasie dyskusji nad budową meczetów. Chociaż, z drugiej strony - jak pokazują dane z końca lat dziewięćdziesiątych - najwięcej sporów ma charakter sąsiedzki (67\%) (Wolf-Almanasreh 1999: 105-106).

Regionem, w którym żyje najwięcej Gastarbeiterów, jest licząca $18 \mathrm{mln}$ mieszkańców Nadrenia Północna-Westfalia. W roczniku statystycznym za rok 2010 podano, że wśród $17 \mathrm{mln} 971$ tys. mieszkańców prawie 1,5 mln to obcokrajowcy (Ausländer mit Migrations Hintergrund im engeren Sinne) (zob. Statistisches... 2010). O występujących w miastach tego regionu wzorcach segregacji dowiadujemy się na podstawie badań uwzględniających takie wskaźniki, jak (Strohmeier, Alic 2006: 7-18): 
1. liczba obcokrajowców wobec ogólnej liczby mieszkańców (wskaźnik segregacji etnicznej),

2. proporcje pomiędzy młodzieżą do lat 18. w stosunku do ludności w przedziale wieku 18-60 lat (jako wskaźnik segregacji demograficznej) i odsetek pracujących fizycznie (Arbeiteranteil) wobec ogółu zatrudnionych (jako wskaźnik segregacji społecznej).

Na podstawie tych badań i przy założeniu, że społeczno-strukturalne różnice $\mathrm{w}$ poszczególnych miastach są względnie stabilne, można powiedzieć, iż we wszystkich miastach Nadrenii Północnej-Westfalii obserwujemy wyraźny wzrost wskaźników mówiących o segregacji społecznej i wysoką korelację wskaźników segregacji społecznej z segregacją etniczną. Możemy przy tym wyróżnić dwa typy miast (Strohmeier, Alic 2006: 29-30).

Typ 1: przykładem są Wuppertal i Essen, gdzie mamy do czynienia z wyraźną polaryzacją przestrzenną i podziałem na dwie strefy - strefę z wysokim udziałem obcokrajowców (w Essen dzielnice północne, w Wuppertalu - Tallanen) i strefę $\mathrm{z}$ małym ich odsetkiem ( $\mathrm{w}$ Essen dzielnice południowe, w Wuppertalu - Hanglagen).

Typ 2: przykładem są Bielefeld i Kolonia, gdzie zamiast polaryzacji przestrzennej mamy do czynienia $\mathrm{z}$ jednej strony $\mathrm{z}$ etniczną segregacją występującą $\mathrm{w}$ różnych częściach miasta, ale bez wyraźnego podziału, zaś $\mathrm{z}$ drugiej - $\mathrm{z}$ wzrastającą koncentracją segregacji $\mathrm{w}$ innych częściach miasta (Bilefeld - centrum, Kolonia - prawy brzeg).

Tabela. Wskaźnik segregacji wybranych narodowości, Kolonia 1980-2000

\begin{tabular}{|l|c|c|c|c|c|}
\hline \multicolumn{1}{|c|}{ Kraj pochodzenia } & $\mathbf{1 9 8 0}$ & $\mathbf{1 9 8 5}$ & $\mathbf{1 9 9 0}$ & $\mathbf{1 9 9 5}$ & $\mathbf{2 0 0 0}$ \\
\hline Turcja & 35,4 & 36,9 & 36,1 & 34,6 & 35,3 \\
\hline Włochy & 31,8 & 30,9 & 29,8 & 27,4 & 25,6 \\
\hline Jugosławia & 25,9 & 27,1 & 28,7 & 28,5 & 25,9 \\
\hline Grecja & 36,4 & 33,5 & 30,8 & 28,8 & 25,3 \\
\hline $\begin{array}{l}\text { Pozostali nieczłonkowie } \\
\text { Unii Europejskiej }\end{array}$ & 42,7 & 48,0 & 40,7 & 48,3 & 42,3 \\
\hline Obcokrajowcy ogółem & 27,1 & 27,6 & 26,7 & 25,3 & 23,8 \\
\hline
\end{tabular}

Źródło: Strohmeier, Alic 2006: 31.

Szczególnym przypadkiem miasta w Nadrenii Północnej-Westfalii jest Duisburg. Na początku tego wieku żyło tam 88 tys. obcokrajowców, z czego 53 tys. Turków. Więcej niż połowa mieszka tam od przeszło dziesięciu lat, $\mathrm{w}$ ostatnich pięciu latach 10 tys. $\mathrm{z}$ nich uzyskało obywatelstwo niemieckie. Szacuje się przy tym, że $w$ perspektywie najbliższych piętnastu lat $1 / 3$ urodzonych tam dzieci będzie dziećmi obcokrajowców (Grandt 1999: 59-60). 
Dzielnicą Duisburga, w której mieszka najwięcej obcokrajowców, jest leżące na północy miasta Marxloh. Jeszcze w połowie XX wieku miała ona charakter przemysłowy, zdominowany przez przemysł hutniczy. Jego upadek spowodował wzrost bezrobocia, sięgający pod koniec ubiegłego stulecia $20,1 \%$. Obecnie mieszkańcy pytani o najważniejsze problemy wskazują na pierwszym miejscu problemy we współżyciu z obcokrajowcami, na drugim (zarówno wśród Niemców, jak i wśród obcokrajowców) na bezrobocie (Grandt 1999: 65-66).

Pod względem miejsca zamieszkania obcokrajowców struktura miasta nie jest homogeniczna. W Duisburgu wyróżnić można bowiem 6 różnych obszarów, w których występują odmienne relacje pomiędzy ludnością niemiecką i obcokrajowcami:

1. demograficznie zestarzałe „jądro niemieckiej ludności” bez ludności obcej,

2. obszar zamieszkały przez rodziny niemieckie i przedstawicieli mniejszości migracyjnych,

3. obszar z przewagą mieszkań komunalnych, miejsce napływu rodzin obcokrajowców,

4. „miejsca specjalne” zamieszkałe przez cudzoziemców zamieszkałych w ośrodkach dla obcokrajowców,

5. części dzielnic zamieszkałych przed obcokrajowców ze względnie wysoką liczbą mniejszości niemieckiej (młodzieży),

6. ,ją̧dro części miasta zamieszkałej przez obcokrajowców" ze średnią gęstością zaludnienia i „zestarzałą” niemiecką mniejszością.

Poszczególne dzielnice i kwartały miasta różnią się pod względem charakteru kontaktów sąsiedzkich, perspektyw zawodowych i problemów wynikających z odmienności kulturowej. Tym, co łączy „niemiecką” część dzielnic z częściami zamieszkałymi przez obcokrajowców, jest podobny charakter kontaktów sąsiedzkich ( $w$ większości w ramach własnej grupy etnicznej - przypadek „1”, „3” i „6"). Z kolei ludność zamieszkałą w obszarach "2" i ",5" cechują bardziej intensywne kontakty (Grandt 1999: 65-66).

Jak wykazują odpowiedzi na pytanie postawione $\mathrm{w}$ badaniach prowadzonych przez Friedrich-Ebert-Stiftung: „Czy ma Pan/Pani kontakty z osobami, które mają inną przynależność państwową niż Pana/Pani własna?", wyraźna jest zależność pomiędzy miejscem zamieszkania a kontaktami osobistymi: mieszkańcy obszaru "6" mają najmniej kontaktów z Niemcami, a jednocześnie $66 \%$ tych mieszkańców jest zadowolonych ze swojego miejsca zamieszkania (Grandt 1999: 65-66). Mieszkańcy obszaru „3” mają z kolei najmniej kontaktów sąsiedzkich ze swoimi sąsiadami (23\% nie zna swojego sąsiada), przy czym zadowolonych $\mathrm{z}$ miejsca zamieszkania jest $\mathrm{w}$ tym przypadku tyko 46\% mieszkańców (Grandt 1999: 67-68). 
O coraz większych problemach $\mathrm{z}$ imigrantami w Duisburgu donosiła ostatnio stacja Deutsche Welle. Tym razem chodziło o przybyszów z Bułgarii i Rumunii, osiedlających się w dzielnicy Hochfeld. Rdzenni Niemcy wytykają im niechęć do utrzymywania porządku, prace na czarno, kradzieże i awantury na ulicach. Młodym Bułgarkom zarzuca się prostytucję. Bardzo często myli się przy tym Bułgarów i Rumunów z Romami, „wrzucanymi automatycznie" do tej samej grupy narodowościowej. Co jednak ciekawe, rzecznik prasowy policji w Duisburgu nie potwierdza tychże doniesień prasowych, wskazując, że w latach 2006-2011 spadła o 40\% liczba drobnych kradzieży, odnotowano też wyraźny spadek liczby włamań do mieszkań i domów jednorodzinnych (Grunau, Pawlak 2012).

\section{BIBLIOGRAFIA}

Babiński G. (2001), Lokalność - pogranicza - globalizacja. Refleksja nad kierunkami badań nad wspótczesnymi przemianami pogranicza zachodniego, [w:] Transgraniczność w perspektywie socjologicznej: kontynuacje $i$ wyzwania, t. 2, red. J. Leszkowicz-Baczyński, Lubuskie Towarzystwo Naukowe, Zielona Góra.

Bauman Z. (2000), Globalizacja. I co z tego dla ludzi wynika, PIW, Warszawa.

Chałasiński J. (1935), Antagonizm polsko-niemiecki w osadzie "Kopalnia” na Górnym Śląsku, Dom Książki Polskiej, Warszawa.

Chałupczak H., Michalik E. (2006), Mniejszości narodowe i etniczne w procesach transformacji $i$ integracji, Wydawnictwo UMCS, Lublin.

Ghettos oder ethnische Kolonie? Entwicklungschancen von Stadtteilen mit hohem Zuwandereranteil (1999), Forschungsinstitut der Friedrich-Ebert-Stiftung, Bonn.

Grandt B. (1999), Von Nachbarschaften und Nahkampfzonen: Fremdheit und Vertrauen, [w:] Ghettos oder ethnische Kolonie? Entwicklungschancen von Stadtteilen mit hohem Zuwandereranteil, Forschungsinstitut der Friedrich-Ebert-Stiftung, Bonn.

Grunau A., Pawlak A. (2012), Coraz większy problem z imigrantami w Duisburgu, [w:] „Onet.Wiadomości" 12.02.2012, http:/ / wiadomosci.onet.pl/ raporty/deutsche-wellew-onecie/coraz-wiekszy-problem-z-imigrantami-w-duisburgu,1,5024523,wiadomosc. html [dostęp: 22.10.2012].

Kleff H.-G. (1999), Die Bevölkerung türkischer Herkunft in Berlin-Kreuzberg - eine Bestandsaufnahme, [w:] Ghettos oder ethnische Kolonie? Entwicklungschancen von Stadtteilen mit hohem Zuwandereranteil, Forschungsinstitut der Friedrich-Ebert-Stiftung, Bonn.

Kłoskowska A. (1996), Kultury narodowe u korzeni, Wydawnictwo Naukowe PWN, Warszawa.

Kurcz Z. (1995), Mniejszość niemiecka w Polsce, Wydawnictwo Uniwersytetu Wrocławskiego, Wrocław.

Latoszek M. (1990), Kaszubi - ich lokalizacja, liczebność w obrębie obszaru dialektu kaszubskiego i jego bezpośrednim sasiedztwie, [w:] Kaszubi. Monografia socjologiczna, red. M. Latoszek, Wydawnictwo WSP, Rzeszów. 
Lisiecki S. (1991), Robotnicy cudzoziemscy w strukturze społeczeństwa zachodnioniemieckiego, Instytut Zachodni, Poznań.

Ossowski S. (1970 [1947]), Zagadnienie więzi regionalnej i więzi narodowej (z badań w Giełczynie), [w:] Ziemie Zachodnie w polskiej literaturze socjologicznej. Wybór tekstów, red. A. Kwilecki, Instytut Zachodni, Poznań.

Statistisches Jahrbuch (2010), Statistisches Bundesamt, Wiesbaden.

Strohmeier K.P., Alic S. (2006), Segregation in den Städten, Forschungsinstitut der Friedrich-Ebert-Stiftung, Bonn.

Synak B. (2000), Kaszubi dzisiaj. Rys socjologiczny, [w:] Pomorze - mała ojczyzna Kaszubów, red. J. Borzyszkowski, P. Albrecht, Zrzeszenie Kaszubsko-Pomorskie, Gdańsk.

Szczepański Marek S. (1999), Region pogranicza kulturowego w perspektywie socjologicznej. Przypadek Górnego Ślaska, [w:] Transgraniczność w perspektywie socjologicznej, red. L. Gołdyka, J. Leszkowicz-Baczyński, L. Szczegóła, M. Zielińska, Lubuskie Towarzystwo Naukowe, Zielona Góra.

Toffler A. (1974), Szok przyszłości, PIW, Warszawa.

Virilio P. (2008), Prędkość i polityka, Wydawnictwo Sic!, Warszawa.

Wolf-Almanasreh R. (1999), "Wir sind alle überfordert ...!” Konfliktmanagement und Problemlösungsstrategien in multi-ethnischen Stadtteilen, [w:] Ghettos oder ethnische Kolonie? Entwicklungschancen von Stadtteilen mit hohem Zuwandereranteil, Forschungsinstitut der Friedrich-Ebert-Stiftung, Bonn.

Zander P. (2010), New Borders and New Spaces: The Case of The Asylum Seeker in Strasbourg, France, "Quaestiones Geographicae” no. 29(4). 